\title{
Effect of Climate Change on Cropping Pattern of Vegetables in Madhya Pradesh, India
}

\author{
Shobha Sanodiya ${ }^{1}$, Kinjulck C. Singh ${ }^{2}$, Varsha Shrivastava ${ }^{3 *}$ and Chandrajit Singh ${ }^{2}$ \\ ${ }^{1}$ Department of Extension Education, ${ }^{2}$ KVK, Rewa, JNKVV, Jabalpur, M.P., India \\ ${ }^{3}$ ATARI, Jabalpur, M.P., India \\ *Corresponding author
}

\begin{abstract}
A B S T R A C T
\section{Keywords}

Socio-economic status, Climate change, Cropping pattern, Vegetable cultivation

Article Info

Accepted:

12 March 2019

Available Online:

10 April 2019

The study was carried out in seoni district of Madhya Pradesh to assess the effect of Climate change on cropping pattern of vegetables. Six villages of Seoni block were selected on the basis maximum area under vegetable crops. Total 120 vegetable growers were selected by simple random sampling method. The study reveals that more than half of the vegetable growers had medium socio-economic status and half of the vegetable growers had low level of knowledge towards climate change. Near to two third of the growers shifted their cropping pattern from potato- Cabbage - cucumber to Maize - Pea Musk melon due to climate change. The results of correlation analysis shows that occupation and knowledge level of the vegetable growers had positive and significant correlation with effect of climate change on cropping pattern of vegetables. The vegetable growers faced economic, market related, technical, situational, extension and institutional related problems in vegetable cultivation. Planners and development workers should formulate policies to improve the knowledge towards the climate and design a procedure to overcome these problems.
\end{abstract}

\section{Introduction}

Vegetables play a vital role in the maintenance of human health and cheapest sources of natural protective food, contributing carbohydrates, vitamins and minerals in human diet (Choudhury, 2006). A balanced diet is essential to sustain good health. For a well-balanced diet, about 300 gram vegetables are required containing root vegetable, green vegetables and others vegetables, but only 130 grams per capita is available. Most of the leafy vegetables and root crops are rich in minerals like $\mathrm{Ca}, \mathrm{Fe}$, and phosphorous some leafy vegetables are rich in microelements like copper, manganese zinc and vitamin $\mathrm{A}, \mathrm{B}, \mathrm{C}$. In the vegetable production climate plays a major role and now a day's climate change is rapidly affecting the vegetable production.

Climate change is a statistical variation in properties of the climate system that include in global temperature, rainfall, sunlight, 
precipitation etc. due to human and natural drivers activity. Agriculture production depends on environmental, varietal and management factors. Climate plays a major role as its positive and negative impact immediately influences crop productivity. Awareness among the farmers about the climate change is very necessary for crop output in terms of production.

For proper growth and development, all vegetable requires an optimum temperature which varies from crop to crop and also limits the range and production of many crops and high temperature with low precipitation will reduced the availability of irrigation water and at the same time increased evapotranspiration leads to severe water stress resulting low yield and quality of vegetable crops (Devi, 2017). A little change in the climatic parameters will bring drastic changes in the quality and nutritional value of vegetables and also affect the post harvest quality and basis for severe losses and affect food safety during storage. (Cotty and JaimeGarcia, 2007). Besides these losses also affects insect pest and disease incidence and weed infestation in vegetable crops (Vermeulen et al., 2010). In this view climate factors affects the vegetable production. Farmer's knowledge about the climate is more important to mitigate the ill effect of weather or climate to some extent. In the recent years extreme weather events like excessive and deficit rainfall, flood, severe frost, temperature and drought are occurring more commonly affecting agricultural production and productivity which leads to decrease farmer's income (Bhan et al., 2014).

A lower agricultural production and productivity due to climate change has implication for food prices, which in turn affect the livelihood and food security status of household in a country. Under this circumstances improved and sustainable agriculture technology according to forecast based, agro advisories and full information about factor effecting of climate change are more useful to reduce vulnerability and improve adaptability of agriculture to climate change. In Seoni district of Madhya Pradesh major vegetable crops grown are Tomato, Onion, Brinjal, Chili, Cucurbits. In a vegetable growing area of a Seoni many factor are available which directly connected with climate change and like average temperature increase, change in rainfall amount and pattern, change in climatic variability and extreme events, weed, pest and pathogen. Keeping in view of the above points, the present study was carried out with following objectives:

To know the personal, socio-economic and psychological profile of vegetable growers.

To study effect of climate change on cropping pattern of vegetable crops.

To identify the various problems faced by vegetable growers.

\section{Materials and Methods}

The present study was conducted in Seoni district of Madhya Pradesh. The Seoni district is located in the southern part of Madhya Pradesh. The district lies between latitude $21^{\circ}$ $36^{\prime}$ to $22^{\circ} 57^{\prime}$ North and longitude $79^{\circ} 19^{\prime}$ to $80^{\circ} 17^{\prime}$ East. Out of the 8 blocks, only Seoni block was selected purposively because it has the second position of the vegetable production and area. The block comprises of 289 villages. A list of vegetable crops growing in the villages were prepared on the basis of their production, out of which 6 villages Mungwani khurd, Mungwani kala, Simariya, Khairy, Singhodi and Jamuniya were selected randomly on the basis of availability of vegetable growers and adopted by KVK Seoni. A list of vegetable growers from selected villages was prepared with the help of RAEOs. To make sample of 120 
respondents for the present study the 20.00 per cent vegetable growers from the total farmer in selected villages of Seoni block through proportionate random sampling method. A well structured and pre tested schedule was used to collect information from the vegetable growers.

\section{Results and Discussion}

\section{Personal and Socio economic status of the vegetable growers}

The perusal of data presented in table 1 indicates that out of the total vegetable growers, majority $(65.00 \%)$ of growers belonged to middle age group. The result is consonance with the findings of Pyasi, 2009 and Natya, 2011. A sizable group of the farmers $(44.16 \%)$ were educated up to higher secondary level and 20.00 per cent were educated up to high school level, while 18.34 per cent were illiterate and only 17.50 per cent educated up to college level. It was also noted that majority of growers $(72.50 \%)$ were engaged in vegetable cultivation. A sizable group of vegetable growers $(46.67 \%)$ had marginal size of land holding followed by 36.67 per cent small size of land holding, 15.83 per cent had medium size land holding and very few $(0.83 \%)$ had large size of land holding.

Majority of the growers $(60.83 \%)$ were found in low income category followed by medium income group $(28.33 \%)$ and high income group $(10.84 \%)$. Similar trend was observed in the study of Neerja et al., (2016). Majority of the vegetable growers $(62.50 \%)$ had medium farm power followed by 20.83 per cent had low farm power and 16.67 per cent had high farm power. The percentage of area under vegetable crops shows the area under vegetable cultivation in their total land holding. Majority of the growers (63.34\%) had 1-25 percent area under vegetable crops.
Near to one forth vegetable growers $(23.33 \%)$ had 26-50 per cent area and 13.33 per cent had 51-75 percent area under vegetable crops.

It can be also furnished from that majority of the vegetable growers $(63.33 \%)$ had 6-10 tonne production, while 20 per cent had 1-5 tonne production and 16.67 per cent had above 10 tonne production of vegetable annually. Near to three fourth growers (74.17\%) had medium farming experience, while 18.33 per cent had high farming experience and few farmers $(7.50 \%)$ had low farming experience.

Out of the total vegetable growers, 52.50 per cent had medium socio-economic status while 37.50 per cent had low socio-economic status, whereas 10.00 per cent had high socioeconomic status.

\section{Psychological variables}

The data presented in table 2 revealed that out of the total vegetable growers, more than half of the growers $(57.50 \%)$ were belonged to medium level of scientific orientation followed by 27.50 per cent had high scientific orientation and 15.00 per cent had low scientific orientation towards vegetable cultivation. Majority of the growers (66.67\%) had medium risk bearing ability, 18.33 per cent had high risk bearing ability and 15.00 per cent had low risk bearing ability towards the vegetable cultivation. Out of the total vegetable growers, 63.33 per cent had medium economic motivation, 26.67 per cent had high economic motivation and 10.00 per cent had low economic motivation towards vegetable cultivation.

\section{Knowledge level towards climate change}

Knowledge plays a vital role in adoption of technology. Knowledge towards climate change will help the farmers in managing 
vegetable cultivation practices in phase of disruptive climatic events. Half of the farmers $(50.00 \%)$ had low level of knowledge towards change in rainfall pattern and rainfall distribution, while 40.00 per cent had medium and only 10.00 per cent vegetable growers had high level of knowledge towards change in rainfall pattern and rainfall distribution on vegetable cultivation. Similarly higher percentage of the vegetable growers $(56.67 \%)$ had low level of knowledge followed by 23.33 per cent had medium and 20.00 per cent had high level of knowledge towards change in temperature (Table 3).

Out of total vegetable growers, 50.00 per cent had low knowledge level towards climate change in concern of vegetable production, whereas 44.17 per cent had medium knowledge level and very few vegetable growers $(5.83 \%)$ had high knowledge level of knowledge related to climate change

\section{Effect of climate change on cropping pattern of vegetable crops}

Out of the total vegetable growers, 62.50 per cent farmers shifted from old cropping pattern Potato - Cabbage - cucumber to new cropping pattern Maize - Pea - Musk Melon due to climate change followed by those vegetable growers $(25.00 \%)$ who shifted from old cropping pattern Okra - Pea - Tomato to new cropping pattern Pulses - Tomato - cabbage. Rest of the vegetable growers (12.50\%) shifted from Bitter gourd - Garlic - Pea to Maize - French bean - Colocasia due to climate change.

Zero order correlation coefficient between independent variables and the effect of climate change on cropping pattern of vegetable crops revealed that the effect of climate change on cropping pattern of vegetable crops had positive and significant relationship with occupation at 0.01 level of probability and knowledge level at 0.05 level of probability (Table 6).

In case of age, farm power, annual production, and economic motivation of vegetable growers were found to have positive and non-significant correlation with effect of climate change on cropping pattern of vegetable crop whereas education, size of land holding, percentage area under vegetable crop, socio-economic status, annual income, farming experience, scientific orientation, risk bearing ability, showed negative and nonsignificant correlation with effect of climate change on cropping pattern of vegetable crop.

\section{Problems faced by vegetable growers}

The problems reported by the growers in production of vegetable crops were lack of fund to purchase agriculture input $(93.33 \%)$ is the first economic problem, the second and third problems were highest cost of fertilizer, seed, equipment and pesticide $(81.67 \%)$ and high labour cost (77.50\%). The fourth problem was lack of loan facility $(68.33 \%)$. In case of the market related problem low price of vegetable in market $(84.17 \%)$ received first rank followed by lack of knowledge of market price of vegetable $(75.83 \%)$ with second rank, irregularity of market facility (77.50\%) ranked third and timely unavailability of fertilizer, seed and insecticide etc. in market $(75.00 \%)$ received forth rank (Table 5).

It is also furnished that Lack of knowledge of high production variety $(75.83 \%)$ was first technical problem, followed by training related problem $(75.00 \%)$, lack of soil testing facility (74.17\%), lack of knowledge about quantity and medicine for seed treatment $(71.67 \%)$ and lack of knowledge of pest and disease were technical problems in vegetable cultivation. Similar study has been done by Sahu et al., (2013). 
Table.1 Personal and socio-economic status of the vegetable growers

\begin{tabular}{|c|c|c|}
\hline Categories & Frequency & Percentage \\
\hline \multicolumn{3}{|l|}{ Age } \\
\hline Young age group & 26 & 21.66 \\
\hline Middle age group & 78 & 65.00 \\
\hline Old age group & 16 & 13.34 \\
\hline \multicolumn{3}{|l|}{ Education } \\
\hline Illiterate & 22 & 18.34 \\
\hline Up to high school & 24 & 20.00 \\
\hline Up to higher secondary & 53 & 44.16 \\
\hline Up to College & 21 & 17.50 \\
\hline \multicolumn{3}{|l|}{ Occupation } \\
\hline Vegetable Cultivation & 87 & $\mathbf{7 2 . 5 0}$ \\
\hline Vegetable Cultivation + labour & 15 & 12.50 \\
\hline Vegetable Cultivation + business & 10 & 8.33 \\
\hline Vegetable Cultivation + service & 8 & 6.67 \\
\hline \multicolumn{3}{|l|}{ Size of Land Holding } \\
\hline Marginal farmer & 56 & 46.67 \\
\hline Small farmer & 44 & 36.67 \\
\hline Medium farmer & 19 & 15.83 \\
\hline Large farmer & 01 & 0.83 \\
\hline \multicolumn{3}{|l|}{ Annual income } \\
\hline Low & 73 & 60.83 \\
\hline Medium & 34 & 28.33 \\
\hline High & 13 & 10.84 \\
\hline \multicolumn{3}{|l|}{ Farm power } \\
\hline Low & 25 & 20.83 \\
\hline Medium & 75 & 62.50 \\
\hline High & 20 & 16.67 \\
\hline \multicolumn{3}{|c|}{ Percentage of area under vegetable crops } \\
\hline$(1-25 \%)$ area & 76 & 63.34 \\
\hline$(26-50 \%)$ area & 28 & 23.33 \\
\hline$(51-75 \%)$ area & 16 & 13.33 \\
\hline \multicolumn{3}{|c|}{ Annual production of vegetable crops } \\
\hline $1-5$ tonne & 24 & 20.00 \\
\hline 6-10 tonne & 76 & 63.33 \\
\hline Above 10 tonne & 20 & 16.67 \\
\hline \multicolumn{3}{|l|}{ Farming experience } \\
\hline Low & 09 & 07.50 \\
\hline Medium & 89 & 74.17 \\
\hline High & 22 & 18.33 \\
\hline \multicolumn{3}{|l|}{ Socio economic status } \\
\hline Low & 45 & 37.50 \\
\hline Medium & 63 & $\mathbf{5 2 . 5 0}$ \\
\hline High & 12 & 10.00 \\
\hline
\end{tabular}


Table.2 Psychological variables of vegetable growers

\begin{tabular}{|c|c|c|}
\hline Categories & Frequency & Percentage \\
\hline \multicolumn{3}{|c|}{ Scientific orientation } \\
\hline Low & 18 & 15.00 \\
\hline Medium & 69 & 57.50 \\
\hline High & 33 & 27.50 \\
\hline \multicolumn{3}{|c|}{ Risk bearing ability } \\
\hline Low & 18 & 15.00 \\
\hline Medium & 80 & 66.67 \\
\hline High & 22 & 18.33 \\
\hline \multicolumn{3}{|c|}{ Economic motivation } \\
\hline Low & 12 & 10.00 \\
\hline Medium & 76 & 63.33 \\
\hline High & 32 & 26.67 \\
\hline
\end{tabular}

Table.3 Knowledge level towards the impact of climate change on vegetable crops

\begin{tabular}{|c|c|c|}
\hline \multirow{2}{*}{\multicolumn{3}{|c|}{ Knowledge level towards change in rainfall pattern and rainfall distribution }} \\
\hline & & \\
\hline Categories & Frequency & Percentage \\
\hline Low & 60 & $\mathbf{5 0 . 0 0}$ \\
\hline Medium & 48 & 40.00 \\
\hline High & 12 & 10.00 \\
\hline \multicolumn{3}{|c|}{ Knowledge level towards change in temperature } \\
\hline Low & 68 & 56.67 \\
\hline Medium & 28 & 23.33 \\
\hline High & 24 & 20.00 \\
\hline \multicolumn{3}{|c|}{ Knowledge level towards climate change } \\
\hline Low & 60 & 50.00 \\
\hline Medium & 53 & 44.17 \\
\hline High & 7 & 5.83 \\
\hline
\end{tabular}

Table.4 Effect of climate change on cropping pattern of vegetable crops

\begin{tabular}{|l|l|c|c|}
\hline Old cropping pattern & New cropping pattern & Frequency & Percentage \\
\hline $\begin{array}{l}\text { Potato - Cabbage } \\
\text { cucumber }\end{array}$ & Maize - Pea - Musk melon & 75 & $\mathbf{6 2 . 5 0}$ \\
\hline Okra - Pea - Tomato & Pulses - Tomato - cabbage & 30 & $\mathbf{2 5 . 0 0}$ \\
\hline Bitter guard - Garlic - Pea & $\begin{array}{l}\text { Maize - French bean - } \\
\text { Colocasia }\end{array}$ & 15 & $\mathbf{1 2 . 5 0}$ \\
\hline Total & & $\mathbf{1 2 0}$ & $\mathbf{1 0 0 . 0 0}$ \\
\hline
\end{tabular}


Table.5 Problems faced by vegetable growers in vegetable cultivation

\begin{tabular}{|c|c|c|c|c|}
\hline S. & Problems & Frequency & Percentage & Rank \\
\hline & Economic problem & & & \\
\hline 1. & Lack of fund to purchase agriculture input & 112 & 93.33 & I \\
\hline 2. & $\begin{array}{l}\text { High cost of fertilizer, seed, equipment and } \\
\text { pesticide. }\end{array}$ & 98 & 81.67 & II \\
\hline 3. & High labour cost & 93 & 77.50 & III \\
\hline \multirow[t]{2}{*}{4.} & Lack of loan facility & 82 & 68.33 & IV \\
\hline & Market related problem & & & \\
\hline 1. & $\begin{array}{l}\text { Lack of knowledge of Market price of } \\
\text { vegetable. }\end{array}$ & 91 & 75.83 & II \\
\hline 2. & Irregularity of market facility & 93 & 77.50 & III \\
\hline 3. & $\begin{array}{l}\text { Timely unavailability of fertilizer, seed and } \\
\text { insecticide etc. in market }\end{array}$ & 90 & 75.00 & IV \\
\hline \multirow[t]{2}{*}{4.} & Low price of vegetable in market & 101 & 84.17 & I \\
\hline & Technical problem & & & \\
\hline 1 & $\begin{array}{l}\text { Lack of knowledge of high production } \\
\text { variety }\end{array}$ & 91 & 75.83 & I \\
\hline 2. & $\begin{array}{l}\text { Lack of knowledge about quantity and } \\
\text { medicine for seed treatment }\end{array}$ & 86 & 71.67 & IV \\
\hline 3. & Training related problem & 90 & 75.00 & II \\
\hline 4. & Lack of knowledge of pest and disease & 86 & 71.67 & IV \\
\hline \multirow[t]{2}{*}{5.} & Lack of soil testing facility & 89 & 74.17 & III \\
\hline & Situational problem & & & \\
\hline 1. & $\begin{array}{l}\text { Unavailability of agricultural inputs in } \\
\text { village }\end{array}$ & 88 & 73.33 & III \\
\hline 2. & Distance between village and market & 93 & 77.50 & I \\
\hline 3. & Irregular supply of electricity & 89 & 74.17 & II \\
\hline \multirow[t]{2}{*}{4.} & Lack of transportation facility & 88 & 73.33 & III \\
\hline & Extension related & & & \\
\hline 1. & $\begin{array}{l}\text { Information are not available in local } \\
\text { language }\end{array}$ & 80 & 66.67 & $\mathbf{V}$ \\
\hline 2. & Irregular visit of RAEO's & 88 & 73.33 & III \\
\hline 3. & Demonstration related problem & 90 & 75.00 & II \\
\hline 4. & Unavailability of technical literature & 85 & 70.83 & IV \\
\hline \multirow[t]{2}{*}{5.} & RAEO's only contact with large farmer & 97 & 80.83 & I \\
\hline & Institutional problem & & & \\
\hline 1. & Lack of co-operative societies in the village & 97 & 80.83 & II \\
\hline 2. & $\begin{array}{l}\text { Unavailability of agricultural input in } \\
\text { society }\end{array}$ & 90 & 75.00 & III \\
\hline 3. & $\begin{array}{l}\text { Not provided timely information by } \\
\text { gram panchayat }\end{array}$ & 105 & 87.50 & I \\
\hline
\end{tabular}


Table.6 Relationship between profile of vegetable growers and effect of climate change on cropping pattern of vegetable crops

\begin{tabular}{|c|l|c|}
\hline S. No. & Independent Variables & Dependent variable (Y) \\
\hline $\mathbf{1 .}$ & Age & $\mathbf{0 . 0 8 3}$ \\
\hline $\mathbf{2 .}$ & Education & $\mathbf{- 0 . 0 1 2}$ \\
\hline $\mathbf{3 .}$ & Occupation & $\mathbf{0 . 2 5 8} * *$ \\
\hline $\mathbf{4 .}$ & Size of land holding & $\mathbf{- 0 . 0 3 2}$ \\
\hline $\mathbf{5 .}$ & Annual income & $\mathbf{- 0 . 0 8 2}$ \\
\hline $\mathbf{6 .}$ & Farm power & $\mathbf{0 . 0 9 2}$ \\
\hline $\mathbf{7 .}$ & percentage of area under vegetable crop & $\mathbf{- 0 . 0 7 0}$ \\
\hline $\mathbf{8 .}$ & Annual production of vegetable crops & $\mathbf{0 . 0 7 3}$ \\
\hline $\mathbf{9 .}$ & Farming experience & $\mathbf{- 0 . 0 8 5}$ \\
\hline $\mathbf{1 0 .}$ & Socio-economic status & $\mathbf{- 0 . 1 3 4}$ \\
\hline $\mathbf{1 1 .}$ & Scientific orientation & $\mathbf{- 0 . 0 0 9}$ \\
\hline $\mathbf{1 2 .}$ & Risk bearing ability & $\mathbf{- 0 . 0 3 3}$ \\
\hline $\mathbf{1 3}$. & Economic motivation & $\mathbf{0 . 0 9 1}$ \\
\hline $\mathbf{1 4}$ & Knowledge level & $\mathbf{0 . 2 1 3}$ \\
\hline
\end{tabular}

$\mathrm{NS}=$ Non- significant

*Significant at 0.05 level of probability

**Significant at 0.01 level of probability.

Distance between village and market $(77.50 \%)$ received first rank in situational problems, irregular supply of electricity (74.17\%) ranked second, unavailability of agricultural inputs in village and lack of transportation facility $(73.33 \%)$ received third rank. In case of extension related problem, RAEO's only contacted with large farmer $(80.83 \%)$ followed by demonstration related problem (75.00\%), irregular visits of RAEO's, unavailability of technical literature $(70.83 \%)$ and information was not available in local language (66.67\%). While timely information was not provided by gram panchayat $(87.50 \%)$, lack of co-operative societies in the village (80.83\%) and unavailability of agricultural input in cooperative societies (75.00) were the institutional problems received by the vegetable growers. These problems should be removed in order to ensure sustainable vegetable cultivation.
It is concluded that 52.50 per cent vegetable growers had medium socio-economic status and about 50.00 per cent vegetable growers had low level of knowledge towards climate change and rest of the farmers had knowledge about the climate change.

To make vegetable growers more literate about climate change, climatic literacy programme should be organised in the villages on regular basis. Total 62.50 per cent growers were shifted their cropping pattern from potato- - Cabbage - Cucumber to Maize - Pea - Musk melon due to climate change. It is evident that vegetable growers were shifting their cropping pattern due to change in climatic events and also low productivity of vegetable crops. Government and development departments should design policies related to climate change to sustain socio economic condition of the vegetable growers and for their livelihood. 


\section{References}

Bhan M, Sahu R, Agrawal KK, Dubey A, Tiwari DK and Singh PP. 2014. Farmer Perception on Climate Change and its impact on agriculture in eastern order of Madhya Pradesh AICRPAM-NICRA. Department of Physics and Agrometererology., J.N.K.V.V. Jabalpur. Technical Bulletin No. DRS/JNKVV/2014-15/01 pp 38.

Choudhury B. 2006. Vegetables, $2^{\text {nd }}$ edition, National Book trust, India.

Cotty PJ and Jamie Garcia R. 2007. Influence of climate on Aflatoxin producing fungi and aflatoxin contamination. International Journal of Food Microbiology. 119(1-2):109-115.

Devi AP, Singh MS, Das SP and Kabiraj J. 2017. Effect of Climate Change on Vegetable Production-A Review. International Journal of Current Microbiology and Applied Sciences. 6(10):477-483.

Natya VK. 2011. A study on adoption of ecofriendly management practices by vegetable growers in Panagar Block of Jabalpur District (M.P.) M.Sc. (Ag.)
Thesis JNKVV, Jabalpur.

Patel N, Dwevedi A, Chouhan S, Sharma R and Singh SRK. 2016. Adoption dynamics of Environment Friendly practices (EFP) in Vegetable cultivation in Madhya Pradesh. International Journal of Agriculture Sciences. 8(52): 2577-2580.

Sahu RP, Sachan VK, and Singh RJ. 2013. Constraints in Adoption of Vegetables Production Technology in Uttarakhand Hills. Technofame-A Journal of Multidisciplinary Advance Research. 2(2):31-34.

Vermeulen SJ, Aggrawal PK, Ainsile A, Anelone C Campbell BM, Challinor AJ, Hansen J, Ingram JSI, Kristjanson P, Lau C, Thronton PK, Wollenberg E.2010. Agriculture, Food Security and Climate change: Outlook for Knowledge, Tools and Action. CCAFS Report $3 . \quad$ Copenhagen, Denmark:CGIAR-ESSP Program on Climate Change, Agriculture and Food Security. Downloaded from http://ccafs.cgiar.org/sites/default/files/p df/ccafs_report_3_low_res_final.pdf

\section{How to cite this article:}

Shobha Sanodiya, Kinjulck C. Singh, Varsha Shrivastava and Chandrajit Singh. 2019. Effect of Climate Change on Cropping Pattern of Vegetables in Madhya Pradesh, India. Int.J.Curr.Microbiol.App.Sci. 8(04): 1350-1358. doi: https://doi.org/10.20546/ijcmas.2019.804.157 